\title{
Article \\ On Earth and as It Is in Heaven-There Is No Sex Trafficking in Heaven: A Qualitative Study Bringing Christian Church Leaders' Anti-Trafficking Viewpoints to Trafficking Discourse
}

\author{
Logan Knight *(D) and Njeri Kagotho (D)
}

check for

updates

Citation: Knight, Logan, and Njeri

Kagotho. 2022. On Earth and as It Is in Heaven-There Is No Sex Trafficking in Heaven: A Qualitative Study Bringing Christian Church

Leaders' Anti-Trafficking Viewpoints to Trafficking Discourse. Religions 13: 65. https://doi.org/10.3390/ rel13010065

Academic Editor: Denise Starkey

Received: 22 November 2021

Accepted: 6 January 2022

Published: 11 January 2022

Publisher's Note: MDPI stays neutral with regard to jurisdictional claims in published maps and institutional affiliations.

Copyright: (C) 2022 by the authors. Licensee MDPI, Basel, Switzerland. This article is an open access article distributed under the terms and conditions of the Creative Commons Attribution (CC BY) license (https:// creativecommons.org/licenses/by/ $4.0 /)$.
College of Social Work, The Ohio State University, Columbus, OH 43210, USA; kagotho.1@osu.edu

* Correspondence: knight.623@osu.edu

\begin{abstract}
There is a lack of contributions in sex trafficking the academic literature from Christian evangelical leaders despite their prominence in global counter-trafficking activism. Given that the academic literature influences professional and pedagogical discourse, the lack of evangelical Christian representation could diminish the complexity of trafficking discourses, limit balanced views of the flaws and strengths of evangelical counter-trafficking, and limit the opportunities for academia to understand and address problematic areas in evangelical counter-trafficking through an emic understanding of evangelical paradigms. Using a phenomenological lens to engage evangelical Christian pastors $(\mathrm{n}=17)$ in the midwestern United States, this study examined the meaning faith leaders attach to counter-trafficking initiatives. Four themes emerged: (1) God cares about survivors of sex trafficking, giving Christians a moral obligation to intervene; (2) God, the Christian, and the survivor all have essential roles in tackling sex trafficking as part of helping humanity; (3) congregations' faith-inspired but imperfect efforts to help an imperfect and complex world create many complexities; and (4) managing complexity involves applying the truths that underpin the Christian worldview, namely that God is good and people are valuable. These findings underscore the need to create an inclusive knowledge-producing forum that allows for a pragmatic exchange of ideas to expand the discourse between multiple counter trafficking actors.
\end{abstract}

Keywords: sex trafficking; Christianity; feminism; standpoint theory

\section{Introduction}

Sex trafficking has gained a place in the global discourse as the crime everyone loves to hate (Bernstein 2018). Its status as a human rights tragedy of epic proportions is validated by social and political apparatuses, such as religion and state, and agencies dedicated to humanist progression. For instance, in 2014, the top global leaders from major world religions including Christianity, Islam, Judaism, Hinduism, and Buddhism signed the Joint Declaration of Religious Leaders Against Modern Slavery (Global Freedom Network 2014). Similarly, the United Nations (2021) urges national actors to eradicate human trafficking by 2030. Many sectors are involved in addressing human trafficking, including law enforcement (Levy and Vandenberg 2016), social service providers (Gerassi and Nichols 2018), and spiritual and religious groups (United States Department of State 2020).

However, due to the moral and legal ambiguities involved in defining and criminalizing 'sex trafficking' and the powerful implications of these for the social and legal censorship/protection of women's sexual rights, several different positions have arisen regarding sex trafficking. These positions are usually encased within three broad narratives that all lay claim to a form of feminist reasoning: (i) sex trafficking is a "myth" promulgated by those who seek to censor women's bodies and regulate their morality (e.g., Kempadoo 2012; Sanghera 2012); (ii) sex trafficking is an existent injustice resulting from patriarchy and other forms of gender-, class-, and race-based oppression which must be abolished (e.g., Bryant-Davis and Tummala-Narra 2017; Farley 2006); (iii) sex trafficking 
is distinct from sex work, the conflation of which combined with carceral feminism results in harm to sex workers especially but also trafficked individuals (e.g., Cojacaru 2016; Gerassi and Nichols 2018). Each broad narrative takes differing stances regarding agency, danger, pleasure, and power regarding women's sexual rights.

\subsection{Christianity's Absent Voices in the Critical Literature on Sex Trafficking}

Despite the complex cultural and political history of the debates around sex trafficking, there seems to be an observable lack of complexity in the academic literature in terms of the voices contributing to the discussions of whether 'sex trafficking' exists, why people frame 'sex trafficking' in particular ways, the harms of a 'sex trafficking' paradigm, and how 'sex trafficking' should be addressed. Notably, contributions to the academic literature from Christian evangelicals involved in counter-trafficking are rare. Evangelical Christianity is typically defined as Christianity that emphasizes the following historical Protestant tenets (Marsden 1987, as cited in Hodge 2006): “(1) Salvation through personal trust in Christ's finished atoning work, (2) a spiritually transformed life marked by moral conduct and personal devotion such as scripture reading and missions, and (3) the Bible as authoritative and reliable ()" (p. 214). The lack of representation by evangelical pastors in academic discourse is a remarkable gap given that Christians are key actors and the influential class within activism and the political arena with regard to trafficking (Bernstein 2018; Zimmerman 2010). For example, the efforts of evangelical Christians contributed significantly to the formulation of "sex trafficking in current anti-trafficking legislation in the United States (Jackson et al. 2017). The rarity of their contributions and representation is even more notable, as among the 'strange bedfellows' of evangelical Christians, radical feminists, political conservatives, philanthropists, celebrities, and the like who confer social and political currency on the abolitionist narrative of sex trafficking, evangelical Christians typically feature as the prime subject of moral scrutiny by scholars who critique the right-wing and left-wing agendas around sex trafficking.

Much of the critique of evangelical Christian counter-trafficking efforts focuses on their alignment with the abolitionist frame of sex trafficking and on the power conferred by the relative affluence and class privilege they have to impose their religiously-derived moral standards or political agendas on others. Scholars have provided numerous critical accounts of how abolitionist views often incorporate a conservative sexual ethic where any sex other than non-transactional sex within a committed, typically monogamous relationship is inherently harmful and/or deviant, which validates sex as a target for intervention by private and public actors at the micro, mezzo, and macro levels (e.g., Bernstein 2018; Zimmerman 2012). Concerns about the evangelical motivation for antisex-trafficking, and evangelical attitudes towards survivors, are also prominent in the critical literature. For instance, the four themes found by Twis and Praetorius (2021) when they analyzed scholarly ethnographies of evangelical counter-sex-trafficking culture in the US described four problems: (1) the centrality of the (fictive) powerless innocent victim in need of rescue, (2) the sexual objectification of the victim at the expense of all other aspects of their personhood, (3) the rescue being for a greater purpose that is meaningful primarily to the counter-trafficker but not necessarily the victim, and (4) a co-optation of survivors' narratives to forward the political and moral agendas of the counter-traffickers. Campbell and Zimmerman (2014) also note that the dominant framework of trafficking accepted by evangelicals typically overlooks the experiences of the most marginalized communities, including immigrants and the LGBTQI community.

The critique of the values, narratives, and agendas of a historically and currently influential group in any social justice endeavor is crucial. It is vital to identify and examine harms inflicted by particular worldviews, paradigms, or practices on those purportedly served by the purveyors and subscribers of these paradigms or practices. Evangelical Christian counter-trafficking would benefit from an absolutely needs-reflexive and critical engagement with the concerns and arguments of scholars such as Bernstein, Cojacaru, Doezema, Kempadoo, Zimmerman, and the like who problematize Christian counter-trafficking 
narratives. Such critiques represent opportunities for the evangelical Christian community to make the changes needed to engage with counter-trafficking in ways that would genuinely meet human needs with sense, dignity, and respect. Twis and Praetorius (2021), for instance, follow their discussion of the four themes with several pertinent recommendations for evangelical Christian counter-traffickers. These include: involving survivors with diverse backgrounds, including racial, sexual, and gender minorities, understanding that including only one or two survivors is not enough; and involving as many survivors as possible in agencies' development of strategies, political action, and direct practice (Twis and Praetorius 2021). Campbell and Zimmerman (2014) highlighted the importance of all parties involved in antitrafficking developing the intellectual resources to critique the prevailing antitrafficking rhetoric.

However, inasmuch as the critiques are important and useful, the lack of evangelical Christian voices in the critical literature creates a bias in perspectives. Possibly reflecting the dominance of secular culture (Bruce-Briggs 1979; Hodge 2019), academic critiques of evangelical Christian counter-trafficking typically mention little if anything at all to appreciate in their efforts, or of ways they could contribute to social change as part of a diverse community. Views are often described as matter-of-fact rather than interpretive, where the evidence is rendered without providing much clarity on underlying ideological premises and circulated with little indication of the authors' reflexivity regarding their stance or discussion of biases. In the absence of evangelical Christian representation, it seems that scholars have been able to describe the values and motivations of evangelical Christian counter-trafficking with little need for reflexivity or engagement with alternative ways of framing what they have observed. Indeed, under such conditions, the viewpoints of the represented groups easily become the privileged reality, where its underlying assumptions and impact are rarely checked or challenged.

As textbooks, publications, conferences, and other academic platforms have an influence on the professional and pedagogical discourse (Hodge 2020), biased viewpoints within academia may endorse stereotypes about evangelical Christians. Academic platforms for such viewpoints too may serve to legitimize and naturalize a negative rather than thoughtfully critical or rigorously analytical attitude that seeks to identify both the strengths of, and flaws in, evangelical counter-trafficking and social justice efforts. The gaps in representation suggest that, while many scholars have rightly pointed out that evangelical Christian anti-trafficking discourse lacks critical moral attention to the impact of its own positions and little curiosity regarding alternative viewpoints (e.g., Bernstein 2018; Campbell and Zimmerman 2014), this lack is endemic across the different positions taken in the moral landscape of trafficking. Apart from a more inclusive inquiry becoming the norm, this lack may continue to mark the various positions in the academic trafficking discourse.

Furthermore, the lack of evangelical Christian representation diminishes the richness, complexity, and usefulness of critical discourses on trafficking. It is the comprehensive representation of all parties involved that would provide the opportunity for individuals with different biases to be accountable to one another (Longino 1990) and prevent groups from remaining systematically ignorant of other groups in ways that would harm the interests of subordinate groups (Anderson 2020). Contingencies of representation become more evident in the presence of others from different positions who are more likely to question the "social positions, interests, background assumptions, biases and other contingent, perspectival features" that shape the "questions, methods, interpretations, and modes of presentation of the claims the knower accepts as knowledge" (Anderson 2020, para. 4). Inclusive inquiry provides opportunities for different viewpoints to engage in ways that produce knowledge useful to different practical interests (Longino 2001), increasing the material, relational, and conceptual resources needed for representations and interpretations of historical and current sociopolitical realities regarding trafficking.

It is also critical to note that, while evangelical Christians are underrepresented in academic discourse, the opposite holds true in the political and activism arenas. The distinction 
between evangelical representation in academic versus activist discourse creates a troubling disconnection between the two domains. It indicates that academics and evangelical Christians are rarely participating in the same conversations. This potentially diminishes the opportunities that academics have to influence evangelicals, with a concomitant loss of opportunity to influence the narratives and priorities of anti-trafficking activism. For instance, scholars across a wide variety of fields have found that anti-trafficking policies can empower anti-migrant policies (De Perez 2015), penalize sex workers (Levy and Jakobsson 2014), and that state and private actors are rarely cognizant of the racist, sexist, and classist paradigms underlying these policy models (Bryant-Davis and Tummala-Narra 2017). These are concerns that evangelical counter-traffickers must consider seriously when wielding their political and social influence as narrators of trafficking; academics need to be deeply engaged with evangelicals in order to keep such concerns or alternative framings of solutions to trafficking at the forefront of activism. Bernstein (2018) observed that, in the field of activism, the abolitionist views of trafficking embedded in carceral approaches have outshouted other feminist visions. Perhaps a more inclusive inquiry in academia would be one critical step among the many needed for redressing the imbalance in the master narratives that currently shape anti-trafficking policy and practice.

Notably, the voices of survivors have been missing from the various discourses on trafficking (Cojacaru 2016; Twis and Praetorius 2021), and academia and activism have only slowly been making progress in acknowledging survivors as equitable producers of trafficking-related knowledge (Gerassi and Nichols 2018). We would add that, alongside survivors and other involved parties, evangelical Christians must be represented in academic discourses. Fully inclusive and democratic discussions would have an emancipatory potential to reduce the power distinctions between different standpoints, where epistemic authority is not essentialized according to a particular social or political identity or agenda (e.g., liberal scholar-activist, evangelical abolitionist, survivor-advocate, etc.). Such discussions also have an objectivizing potential, in that the shared inquiry could "refine the norms of equality so as to distinguish legitimate differences of expertise and competence from illegitimate exercises of social power" (Anderson 2020, para. 77). The truly democratic environment created by such an inclusive inquiry may in turn serve as a bulwark against the "tokenization"1 of survivor representation in trafficking-related matters, a concern that has been reported as organizations attempt to prioritize survivor expertise (Sanders 2015).

\subsection{Standpoint Theory in Anti-Trafficking Discourse}

The seemingly taken-for-granted epistemological superiority of the critical perspectives on evangelical Christian counter-trafficking evoke the questions central to standpoint theory (Anderson 2020) — the questions of privileged perspective and the scope of this privilege: what questions or subject matter the individual can claim privilege over, what aspect of social location the capacity and authority to generate superior knowledge confers, what the specific grounds of this privilege are, the type of epistemic superiority claimed, the other perspectives relative to which it claims epistemic superiority, and the modes of access to that perspective (Anderson 2020, para. 1). Understanding the standpoints of others requires "situated knowledge" - the knowledge that comes from individuals embedded in their particular historical moments and sociocultural contexts, and from recognizing the epistemic advantage that these individuals have pertaining to their situations (Pierre 2014). Acknowledging evangelical Christian counter-traffickers' ability to know why they do what they do and what they see is the impact of their knowledge on their situations will provide access to the knowledge needed to: (1) address the gap in representation and (2) give the critiques of evangelical counter-trafficking efforts a balanced place within trafficking discourses.

\subsection{Study Goals}

We thus seek to address the imbalance in scholarly discussions of trafficking narratives by bringing a representation of Christian perspectives on trafficking to the table. The goal 
is not to take a partisan lens, but to allow participants' voices themselves to be heard with "depth, candor, insight and potential relevance or resonance" (Fraser and MacDougall 2017). Specifically, we sought to answer two questions through a phenomenological lens which foregrounds the lived experience and interpretations of this lived experience of Christian community members:

A. How do Christians experience their faith when faced with the issue of sex trafficking? That is, what does it mean to be a Christian, from the perspectives of practicing Christians themselves, when it comes to the issue of sex trafficking?

B. What rights and responsibilities do Christian faith leaders perceive the following actors in anti-trafficking narratives as having: God, the Christian, and the survivor?

The answers to these questions provide explicit interpretations of Christian countertrafficking agendas, motivations, and approaches by Christians themselves, offering insights that may be overlooked or muted in the current academic discourse and challenging extant views or stereotypes. Answers also provide opportunities to better understand what has been polarizing in Christian perspectives of sex trafficking, and how such polarization could be overcome with the goal of promoting a genuine engagement with diverse viewpoints.

\section{Methods}

As an exploratory qualitative study of the phenomenon of evangelical Christian experience in regard to anti-sex-trafficking, it was important to recruit a diverse crosssection of evangelical church leaders. To increase the likelihood that respondents from these congregations had some familiarity or experience with sex trafficking from a faithbased perspective, we contacted churches from fourteen evangelical denominations who had issued official statements on human trafficking, and independent evangelical churches who had their own anti-trafficking ministry, were supporting an anti-trafficking nonprofit, or had invited anti-trafficking agencies to conduct training for their congregations. An anti-trafficking coalition that served the county was also asked to distribute recruitment materials to their Christian partners. Churches were identified via searching on the Internet, or by information given to us by local pastors and anti-trafficking agencies.

We sent 65 recruitment emails, resulting in eight pastors being recruited. Another seven pastors were recruited via snowball sampling, and two more were referred via other scholars. Participants came from four mainstream denominations and seven independent churches. Eight of these were head pastors and the other seven were pastors of specific ministries in their churches. All had degrees from secular universities, and seven also had degrees from religious institutions. All 17 participants had experience with antitrafficking efforts via volunteering with an anti-trafficking agency or hosting anti-trafficking events at their churches. Four were involved in anti-trafficking ministries in their own churches. Another four were also working with survivors in professional contexts at the time of the interviews either as licensed counselors or social workers, of which two had started their own antitrafficking nonprofit organization. See Table 1 below for further participant details.

All subjects gave their informed consent for inclusion before they participated in the study. The study was approved by the Institutional Review Board of the Ohio State University (study number 2020B0060). The approved study protocol, including all processes for ensuring ethical research-such as ensuring participants' safety, the protection of subjects' privacy, and the confidentiality of their data-was strictly followed. 
Table 1. Participant and Interview Information.

\begin{tabular}{ccc}
\hline Category & Mean/Details & Range \\
\hline Gender & Female $(\mathrm{n}=11) ;$ male $(\mathrm{n}=6)$ & - \\
\hline Marital status & Married $(\mathrm{n}=16) ;$ single $(\mathrm{n}=1)$ & - \\
\hline Race & $\begin{array}{c}\text { White }(\mathrm{n}=12) ; \text { Asian }(\mathrm{n}=4) ; \\
\text { Hispanic }(\mathrm{n}=1)\end{array}$ & 23-70 years \\
\hline Age & 47.4 years & 10-5000 members \\
\hline Size of congregation & 605 members & 1-27 years \\
\hline $\begin{array}{c}\text { Length of time in a pastoral position in } \\
\text { their current congregation }\end{array}$ & 8.79 years & 3-50 years \\
\hline $\begin{array}{c}\text { Total length of time of leadership in } \\
\text { Christian churches }\end{array}$ & 19 years &
\end{tabular}

\subsection{Study Approach}

Interpretative phenomenological analysis (IPA) was chosen as the means of studying the 'essence' or 'phenomenon' of what it means to be a Christian through a 'double hermeneutic', where it is assumed that individuals are actively trying to interpret or make meaning of the people, events, and objects they encounter (Taylor 1985), and the researchers try to interpret this meaning-making from the participants' perspectives (Smith and Osborn 2015). Heidegger (2005) and Merleau-Ponty (1962) asserted that a phenomenological reduction or bracketing is impossible to completely achieve at any point, as people are "beings-in-the-world" (Cooper 1999). As such bracketing is impossible and knowledge is socially produced, the first author conducted the interviews with a disclosure of her salient intersecting social identities as a cis-gender woman, a member of the same faith-based community, as well as a social work researcher invested in promoting truly socially just (and possibly abolitionist where necessary to promote the wellbeing of the vulnerable) approaches to human trafficking.

The social context of the interview as a knowledge production frame itself shapes the knowledge produced and interpretation of the multiple realities involved (Wimpenny and Gass 2000). Speakers shape their speech to fit the situation or their goals, whether or not it is particularly self-conscious (Eckert 2000; Milroy and Gordon 2003; Schilling-Estes 2001). Participants may seek to portray themselves in a favorable light (Linde 1993), or subvert stereotypical representations of Christianity, and so on; interviewees' responses to their interview hinges on their (and not the researcher's) perception of the situation as well as their own goals. In acknowledgement of participants' agency, as well as the responsibility of the researcher to promote equitable participation in the co-production of knowledge, author 1 shared with participants prior to the interview proper about the competing discourses in the anti-trafficking landscape, scholarly criticisms of Christian anti-trafficking, and how the interview was an opportunity for participants' voices to be heard in academia, should they choose. As interpretation of data needs to be sensitive to speakers' agency and goals, this open sharing also promotes analytical rigor, since participants and the interviewer are able to talk openly about why they are sharing what they are sharing and what they hope the consumers of any academic papers/reports resulting from the interview would take away.

\section{Semi-Structured Interviews}

In order to generate rich and detailed descriptions of how participants experienced being a Christian facing a world where an injustice like sex trafficking exists, all interviews began with the elicitation of a story: "Tell me about when you first heard about sex trafficking?", followed by "How did it make you feel?". Questions that directly evoked the influence of participants' faith-based worldviews on their perceptions of sex trafficking included: "What do you think is the church's role in the problem of sex trafficking?" and "Imagine you have just moved to another city and joined a new church. Six months after 
joining this new church, the leadership team calls you in and tells you that they want to help sex trafficking survivors. They say that they would like you to start the ministry. What would your thoughts be about being asked to do this? What do you think that ministry should involve?". The interview guide also contained questions that probed both the influence of participants' faith on their views of sex trafficking and the degree of shared knowledge/perspectives between participants and other sectors involved in anti-trafficking work. Examples of such questions include: "What personal traits or qualities do you think survivors need to be able to succeed?" and "What resources and/or support do you think survivors need to be able to succeed?".

In the initial interview, the interview guide was used with the view that the critical components of the interview were "...the use of reflection, clarification, request for examples and description, and the conveyance of interest through listening techniques" (Jasper 1994, p. 311) to foster participants' telling and interpretation of their experience of being a Christian talking and thinking about sex trafficking. In the follow-up interviews, the interviewer and participants discussed their reflections on the initial interview, and participants further elaborated their viewpoints on trafficking. Interviews were conducted over the principle investigator's organization's Zoom platform to adhere to COVID-19 health and safety regulations. One set of initial and follow-up interviews was conducted via email at the participant's request. All interviews were conducted by author 1 . A total of 16 initial interviews $(M=57 \mathrm{~min}$, range: 39-87 $\mathrm{min})$ and 12 follow-up interviews $(\mathrm{M}=$ $42 \mathrm{~min}$, range: $21-64 \mathrm{~min})$ were conducted.

\subsection{Analysis}

Video recordings of the interviews were watched twice, and transcriptions read three times prior to coding. To help with the interpretive approach, notes were made in the transcriptions on participants' paralinguistic behavior that marked their stances towards the issue being discussed. These behaviors included large gestures, lowered volume, tears, pauses, incredulous laughter, and so on. Initial reflexivity notes were made prior to coding as well. To ground the analysis in the participants' own interpretation of what it means to be a Christian talking and thinking about sex trafficking, in vivo coding and descriptive coding was done iteratively for the first two rounds of coding. This was followed by narrative coding, which included codes such as purpose, setting, plot, character, and characterization (Polkinghorne 1995; Saldaña 2016). Narrative codes were used to further interrogate participants' experiences, since these codes provide another layer of insight into how participants experience events and confer their subjective meaning onto these experiences (Bamberg 2012) and explicate how the different elements in the individual's narrated experiences relate to each other. Initial coding was done by hand, with final iterations of coding done in Nvivo12 (QSR International Pty Ltd. 2020).

The initial list of codes created by in vivo, descriptive, and narrative coding methods was then condensed by combining similar codes. These codes were renamed to reflect similarities of experience and interpretation across participants to further distill the "essence" or essential features of the phenomenon being studied (Davidson and Stayner 1997). This list of codes was re-coded into broader categories or pattern codes that reflected potential emerging themes, configurations, or explanations (Miles and Huberman 1994). Relationships between the pattern codes were then examined, and themes were developed from the relationships between these codes. Initial coding and the first round of pattern coding and development of themes was conducted by author 1. Final rounds of pattern coding and development of themes were conducted by both authors.

To analyze and discuss the themes as social work researchers, we applied standpoint theory (Anderson 2020). For the data in this study, the social location examined was that of the Christian pastor and the privileged perspective being the participants' preferred or expressed faith-based views of anti-sex-trafficking matters. 


\subsection{Positionality and Rigor}

\subsubsection{Positionality}

Researchers' identities and lived experiences influence all phases of qualitative studies from conceptualization through to data presentation. Given this, both authors were transparent about the factors (both mutable and immutable) that informed their positionalities as researchers. The first author is a PhD candidate in a social work program and is a part of the Christian community. In addition to a substantive area of research in the field of human trafficking, she also has a history of involvement in both secular and faith-based anti-trafficking work. The author's intersecting identities gave her insights into the modes of knowledge production and moral thought valued in both communities, and the insider knowledge needed to conduct the semi-structured interviews sensitively and productively. The second author is a PhD-level social worker and a member of a diaspora Christian community. Her scholarship examines institutional factors linked to the well-being of individuals, and in this study she used her knowledge of informal institutions (faith, culture, social mores, etc.) to help make meaning of the advocacy counter-trafficking narratives provided by participants. As foreign-born women, both authors' formative Christian faith developed outside of the United States, and as such their faith is highly influenced by the cultural practices that inform Christianity in their countries. Therefore, to ensure study fidelity the authors consulted with a panel of U.S. based pastors as needed to ensure that the interview protocols were appropriate and that the meanings expressed by the participants were accurately assessed and interpreted.

\subsubsection{Strategies for Credibility and Trustworthiness}

Author 1 wrote the initial interview guide in consultation with author 2. The study design and initial interview guide was then shared with four pastors of different races, genders, and denominational backgrounds for their feedback, and we revised the questions accordingly. The pastors consented to be interviewed to pilot the study design and gave feedback on the study design and results before we began the full version of the study. During the data analysis, we used peer debriefing, member checking (during follow-up interviews), reflexive journaling, and keeping an audit trail of analytic decisions to ensure analytic rigor. One of the original four pastors was able to give feedback on this manuscript prior to submission.

\section{Results}

Four themes emerged from the data analysis: (1) "the divine mandate", with moral obligation as its primary phenomenon; (2) "immutability and change", with the true nature of things as its primary phenomenon, (3) "instrumentality", with divine empowerment interacting with human willingness as its primary phenomenon; and (4) "managing tensions", with complexity as its primary phenomenon.

\subsection{Theme 1: The Divine Mandate}

In this theme, the divine mandate was the participants' foundational paradigm for addressing trafficking. Participants described Christians as having a moral responsibility to help survivors of sex trafficking due to a divine mandate: God himself ${ }^{2}$ requires His children (Christians) to sustain generous, effortful, and compassionate help towards sex trafficking survivors until that help is no longer needed. Overall, the divine mandate encapsulates a moral obligation of the highest degree to help survivors, suggesting that for Christians to not actively address the issue of trafficking or other social justices would be a denial of their very faith identity.

Within the framework of this mandate, participants shared three main reasons for helping trafficking survivors: (i) being 'like God', Christlikeness, or imitating the divine; (ii) obedience to God; and (iii) giving to others what they had received. The first reason participants emphasized was that of being 'like God', where they attributed their desire 
to support survivors to sharing God's values and desires. For instance, Dana described Christians' responsibility to be just like Jesus on earth:

We have a responsibility to be the feet of the Lord (Jesus) on the earth to make a difference. I would say that these victims are like the woman at the well, or the woman that they were going to stone...He took a stand and said, "I'm here for them". And that's our role on the earth.

The second reason in the divine mandate theme for helping survivors was obedience to God. Two sources of instructions from God were described, namely the Bible and direction revelation. According to participants, the Bible made it clear that God expected Christians to engage in social justice issues, in which trafficking was included. Kathy shared this interpretation of the Bible:

I think the church's role in any type of injustice-there's a verse, Matthew 25, "When I was hungry, you gave me something to eat. I was thirsty, you gave me something to drink". It's looking at someone with grace and looking at them through the eyes and the lens of Christ that should motivate us all to want to help other people, as a follower of Christ and as someone who believes $100 \%$ in the Bible. stated:

Similarly, Martha, whose church was extremely active in anti-sex-trafficking work,

Biblically, the Church has a duty to meet the needs of the poor, orphans, widows, and those in need. How that manifests or looks like will look different for each church depending on the people mix of the congregation and resources available to them and vision/plan God gives them to accomplish the needs around them. But, being the Church is all about welcoming the needy, loving the so-called unlovely, and mending the broken hearts and souls of men and women.

While all Christians were given a moral obligation by the Bible to help the needy and vulnerable, participants indicated that more specific calls to focus on the issue of sex trafficking came through direct revelation or appointment from God. Carl described this specificity:

The Holy Spirit has to call a person to that work, because, you know, it's easy to posture and say, like, "I'm against human trafficking", but if you're really going to get involved, that's not a thing that humans really seem to want to do. Especially when it's heartbreaking, and, messy, and you don't see successes, whatever that means, all the time, right? And so, I think that it has to be a movement of God calling a person to that.

Direct revelation from God was depicted as a means of resource distribution and investment - in the face of limited time, finances, manpower, and emotional energy, individuals and congregations could make the decision to prioritize participation in anti-trafficking over other issues due to this direct revelation. Typically, prayer, meditation, journaling, or other reflective activities where participants engaged with God were the means of obtaining this revelation. For instance, Kathy described her journey into becoming heavily involved in anti-trafficking work as beginning with "praying and asking God to stretch me in some way for the new year". In an example involving a congregation rather than an individual, when Dana became aware of the issue of trafficking, she shared that her "first action" was to

call the body to pray and then ask who felt the same calling to assist, whether it be financially to another ministry or to assist maybe in creating something to step in. So we started with gathering around to pray about it and see what they felt they wanted to be part of. Then we started gathering funds to help different ministries.

The third reason for helping survivors in the divine was giving to others what they themselves had received from God. For instance, after describing how God had been good to her, Kathy shared, "Why would we not turn around and give someone else the 
opportunity too, why would we not want to show somebody love and respect and help them whether it's a homeless person on the street, or a woman, a survivor?".

In addition to validating their construction of a divinely ordained obligation to rescue survivors by use of scriptures and testimonies of direct instruction, participants authenticated their constructions of a divine mandate by describing the emotional labor and reward involved. Participants revealed that the divine mandate is not just theology or a kind of moral code; it is a rich, vibrant, heartfelt, emotional experience. The emotional labor was framed in highly emotive descriptions of the experiences involved in counter-trafficking, including horror at the exploitation, awe at receiving such responsibility, joy at observing or envisioning survivors' successes, and so on. For instance, Harriet and Ian both recalled feeling "anger", "sadness", and "overwhelm", and Joan felt "panic" and "grief", when they first encountered sex trafficking. Dana described the necessity of deep empathy with survivors, where Christians had to have "their hearts break to allow some of the trauma to be a part of their own hearts so that they can do something", asserting that, "You cannot make a difference if you're not getting your heart broken and your hands dirty".

The rewards and benefits also authenticate the mandate as having both divine inspiration and sanction, and give further evidence for its morality. For the church and the Christian, the rewards for fulfilling the mandate include personal growth in faith matters, experiences of joy, and other desirable experiences. Illustrating this, Jenny, who worked with survivors in both church and professional contexts, shared that her work with survivors had contributed uniquely to her own spiritual growth, stating, "I think that walking alongside survivors has been the single most factor that has made the Bible come alive to me". Similarly, Tyler mentioned the rewards of serving God:

In the Bible, it talks about lending to God. So, whether they are poor financially or they are poor relationally, or these people who have been trafficked, then they're poor in spirit, right? So, you're lending to the Lord by giving into that. That is the bank in the universe that has the highest interest rate is the bank of God. You can't find a better interest rate out there, you are going to get many, many times over what you have put into that bank.

The benefits for survivors effected through Christian help include survivors achieving their preferred lives, becoming happy through internalizing God's positive viewpoint on them, and gaining socially valued, prestigious, and viable identities and roles within the church and/or the community. For example, Eliza shared that survivors who embrace Jesus as the "lover of your soul, the one who created you for a purpose" would change and want a "real life", where they can "know their identity", "know what they want is worth fighting for", "know their worth", and "not be defined by your circumstance or what happened to you or even what you did in your past". Jenny shared how the survivors' benefits are rewarding to the Christian:

And it's kind of like the same thing for a journey with a survivor. They watch you pour out your heart and you give what you can that's good, and you hope at some point, they'll learn to trust and rest in that and be open to receiving. And what a celebration of joy that is when they do finally rest in it. It makes everything you're doing worthwhile.

Notably, the divine mandate applies not just to the Christians and the church, but also to survivors who have become Christians. Christians have a duty to help survivors because they themselves have been helped by God; survivors too, after being helped, would incur the duty of helping other survivors. Participants did not frame survivors' obligation to take up the mandate explicitly, for instance, words like "must", "should", and "need to" were not used. For example, Joan said:

What I love to see and what I love seeing is someone who is so brave enough, a survivor who would be able to (help other survivors), because it is so hard to relate to a survivor, even if you are the most compassionate and empathetic 
person in the world. It's (the survivor) the best person to reach another person in human trafficking or someone who is trying to get out of human trafficking.

As another example that did not explicitly denote moral obligation, Tina said that one of her "top ten words" for survivors was "friend", because "they've been helped out, now they're going to be a friend to, to help others out". While obligation was not denoted explicitly, participants attributed to survivors not just the ability but also the desire to help other survivors. This suggests a taken-for-granted moral imperative; i.e., helped survivors too come under the divine mandate as specially designated to help other survivors. Figure 1 summarizes the divine mandate:

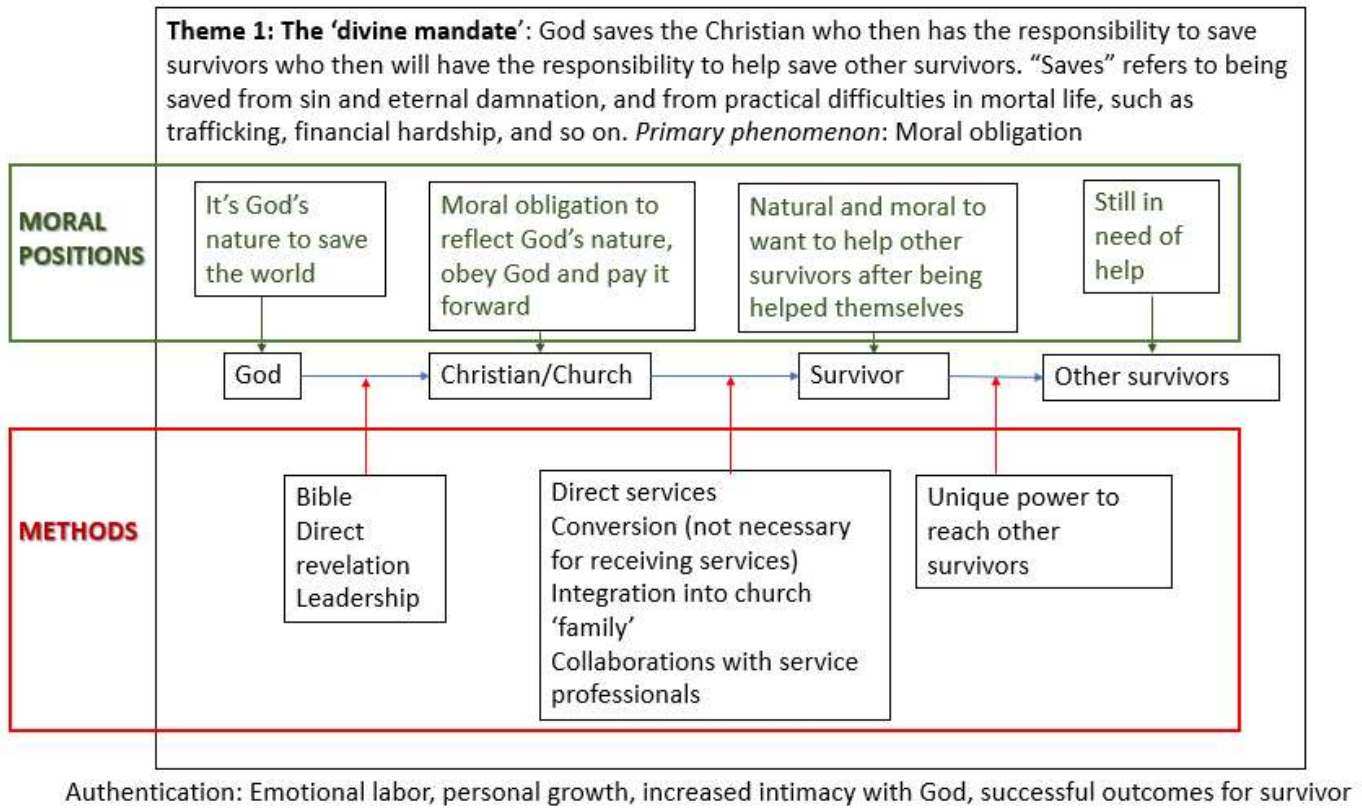

Figure 1. Illustration of the Divine Mandate.

\subsection{Theme 2: Immutability and Change}

'Immutability and change' emerged as another dominant theme. Immutability refers to the unchangeable and constant truths about God or an individual that stand as unassailable certainties. All of the immutable truths described by participants regarding God, themselves/the church, and the survivor are of a positive nature. For instance, Paul described survivors as being the "people that God is super interested in", and referred to Jesus's words and actions regarding the stigmatized individuals of his day, stating that "God left the 99 to get the one. Jesus spent his time with prostitutes and tax collectors", exemplifying one of the timeless immutable truths about God. Jonathan described another unchanging aspect of God (Jesus), stating that, "He (Jesus) is always on the side of the oppressed ... Jesus spoke against the powerful forces that tried to oppress people". Kathy described all people, including survivors, as being equally "approachable to God" because of how He has "put eternity in our hearts". All the claims about God and the survivors in these three examples were based on descriptions of God in the Bible, which is scripture credited within evangelical Christian understanding as being unchangeably true since time began.

Change refers to the transitions that people-both Christians and survivors, as well as the wider society-have to make in order to appropriate the benefits of the immutable truths about the self, God, and the world at large-i.e., to realize their true nature. For instance, Tyler observed that, while a lot of churches are excellent at organizing corporate gatherings like a "well-oiled machine", where members engage in faith activities such as worship and hearing a good sermon, there is still "a lot of room to grow in true discipleship". Jennifer, who was in charge of community services in her church, noted that the biggest problem volunteers in her ministry faced in helping individuals in need was the fear of "not knowing 
what to do" and "not knowing what to say". She shared that it was critical to change not by striving for "perfection" but rather by trying to "get rid of that (pressure/expectation) and really just focus on the simplicity of Jesus".

The theme of 'immutability and change' describes participants' construction of reality that is grounded in their faith-based worldview. The two comprise a single theme because of their relationship: the immutable facts provide the empowerment and reason for making changes; the goal of these changes is the full and joyous experience of these immutable facts of life. Table 2 displays some of the immutable truths and changes pertaining to God, the Christian, and the survivor that were prominent in the data.

Table 2. Prominent Truths and Changes Needed in Participants' Interviews.

\begin{tabular}{|c|c|c|}
\hline Person/Entity & Immutable Truths & Changes Needed \\
\hline Survivor & $\begin{array}{l}\text { - } \quad \text { Possesses great intrinsic value. } \\
\text { - Has great potential. } \\
\text { - } \quad \text { Is the recipient of God's love, empowerment, } \\
\text { - } \quad \text { welcome, and blessing. } \\
\text { - Is called to be the recipient of the churches' help. } \\
\text { - } \quad \text { is called to transmit God's love to others. }\end{array}$ & 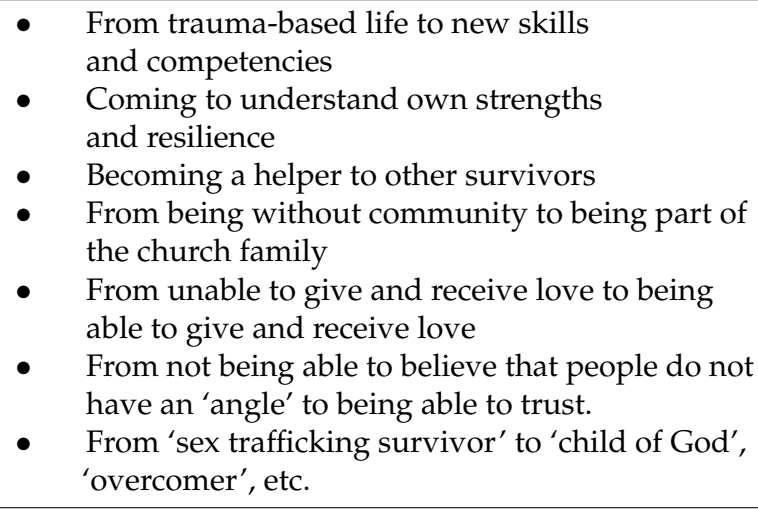 \\
\hline Pastor/church & $\begin{array}{l}\text { - } \quad \text { Possesses a calling/divine mandate. } \\
\text { - } \quad \text { Is required to display consistent love and } \\
\text { commitment to survivor whether or not they are } \\
\text { aware of the divine mandate regarding } \\
\text { survivors; lack of awareness or obedience belies } \\
\text { identity as 'hands and feet' of Christ. } \\
\text { - Benefits from collaboration with others. }\end{array}$ & $\begin{array}{l}\text { - } \quad \text { From ignorant to aware of trafficking } \\
\text { From untrained to trained and competent } \\
\text { to intervene } \\
\text { - } \quad \text { From increasingly compelled to the work } \\
\text { Being given fresh vision and resources for } \\
\text { the work } \\
\text { From not involved to becoming involved in } \\
\text { the work } \\
\text { From too busy/distracted to hearing and obeying } \\
\text { God to intervene in the issue of sex trafficking }\end{array}$ \\
\hline God & $\begin{array}{ll}\text { - } & \text { Loves people. } \\
\text { - } & \text { Is just and powerful. } \\
\text { - } & \text { Is unchanging in nature. }\end{array}$ & - No change needed \\
\hline
\end{tabular}

Communal and personal transformation, whether for the Christian, the church, the survivor, or society at large, involves a return to the true nature of things. All through the interviews, participants basically narrate the sex trafficking survivor as a beloved child of God with a powerful destiny who can achieve their dreams and impact others for good. This identity is already absolutely true of the survivor; the restoration journey or bildungsroman - the journey of growth - is that of realization, not achievement. Eliza, for instance, shared her belief that survivors will heal and thrive when they come to accept the truths about their value, potential, and God's perspectives on them, stating that the most important affirmations they could make are: "I am valuable, I am loved, I am going to change the world".

The journey of realization of one's true nature is described as ongoing for all human parties involved. For instance, Tina noted that whatever traits or resources survivors needed to be successful were those that anyone needed, and Joan stated, after describing survivors' processes of healing and long-term needs, "It's same thing for anybody. I believe that I see what we do here on earth as just continuous fight continuous success stories and we finish this when we die". Just as the divine mandate (see the previous theme) applied to both Christians and survivors, participants describe the Christian and the survivor as 
both being still partway through their journeys of manifesting the immutable truths, with similar trials, joys, need for support, and goals-all under God's care.

\subsection{Theme 3: Instrumentality}

The theme of instrumentality ran through participants' responses. Much of the instrumentality is mutual. For instance, God is able to fulfil his heart's desire to help the survivor through the actions of the Christian; the Christian is empowered by God to help survivors. Jenny, who committed to both a pastoral and a professional career to help survivors of sex trafficking, because God needed Christians to be "the hands and feet of Christ" on earth, shared her need for God's assurance in her work:

I think one of the things that has helped me in this work is to recognize that I'm called to be faithful, not successful. And if I'm doing it to fulfil the call that I have been given by God, then no matter how the day turns out, I will feel like He has been happy with what I've done. And that helps me to be resilient in my work with survivors.

In another example of this mutuality, John decried how people in need, including survivors of trafficking, remain un-helped because the Christians "don't give of themselves, don't give their money, don't give anything because they want to stay in their comfortable homes" and are "stuck in the basement". He also gave a clear example of the empowerment to help survivors when describing his development of training materials on human trafficking: "God has somehow given me the technical writing ability and truly it's just Holy Spirit and me ... She (my editor) said, "You have a gift". It's not a 'gift'. It's the Holy Spirit".

Similarly, the survivor and God are cast in a narrative where the survivor needs God to attain full healing and happiness, and where God has in the transformed survivor a uniquely deft agent to reach other survivors. That is, in the 'God needs the survivor' piece of the narrative, participants emphasize that survivors have the unique ability to help others. For example, Jane shared that due to God doing a "miraculous thing", survivors are "able to help people that others cannot". In the 'survivor needs God' piece of the narrative, God was often described as the source of survivors' authentic healing from trauma:

Anybody who's been abused or trafficked their identity is definitely warpedbased on a lot of untruths. They've got to have a God encounter... All those lies have to be exposed, and only by God. That's what I call an inner healing-where Jesus is able to encounter that person in such a way that they can begin to believe what He says about them. And then once they start believing what He says about them, then healing comes from the inside out.

Ty described the survivor's healing as reliant on God with a very similar narrative:

Everybody wants to change, right? But self-help creates a law in your mind, "I'm going to do this. Then, of course, in a weak moment, what's going to fight against that? Your mind, will and emotions, which is our soul is going to in the heat of the moment is going to fight against that very thing that you set up that you want to do. It really has to be something from the inside, something that changes the very nature of who you are. And the only thing that I'm aware of the entire universe that does that is Jesus ... It's good to have people help, but something needs to change on the inside and that only comes through Jesus. That's the only way for people to have lasting change.

In a poignant illustration of the survivor's need for the help of God, Jenny shared that God is instrumental to the survivor's survival, even outside the survivors' cognizance:

I believe God reaches out even more to those who are in pain and trouble and are looking for something else. So I think that the survivor at times doesn't even realize that there's that inner strength and I believe it's of God. 
Notably, the instrumentality highlights the essential role of each party in participants' anti-trafficking discourse. Mutual instrumentality places a powerful moral prerogative on both the Christian and the survivor; without the willingness of either to cooperate and collaborate with the divine, the salvation of others is hindered. While participants generally shared that nothing effective can take place outside the divine empowerment, within this narrative people have the power to hinder or effect the divine plans of God. For example, Dana stated that even a survivor who has converted to Christianity will not experience the benefit of that transformed life without Christians helping: "The only way to see the power of God in her own life is to have people around her that are showing it by their deeds and not their words"; and Jennifer stated that even a person who has been "rejuvenated (by Jesus) from the inside out" still needs to "be part of the body of Christ. They need to have meaningful relationships, not just sitting in a pew on Sunday once a week for an hour".

Nonetheless, this cooperation must be a heartfelt matter and be freely chosen through sincere agreement (usually involving direct revelation of a 'call' from God to become involved in anti-trafficking) and not moral blackmail, religious pressure, or church politics. For example, Dana mentioned at various places in her interview the importance of "having a heart" and "passion" for the issue of trafficking. Harriet shared, "I remember in college saying that I want to work with women who are coming out of or involved in this lifestyle". She explained, "It was the whole notion of God's calling and your deep desire and they meet in this moment where you're just like 'Oh my gosh'”. Tyler noted the positive outcomes of such heartfelt agreement:

When a person is in love with God, they want to do things that please Him. And His Word says when you delight yourself in the Lord, you're doing things in your life that please Him. He will give you the desires of your heart and all these other things will work out for you. You're not going to have to strive.

In essence, the central role of people's willing cooperation with God's desire to help survivors demonstrates the fundamental place of human agency within participants' faithbased worldviews on trafficking. Reflecting this, Jenny cautioned the church that overruling the survivor's own choices would make the church "just like the pimp":

If she doesn't get that freedom (to make her own choices) and there's pressure from the church to change and receive what we give you, then, that's the kind of thing that tends to drive her back out. They (survivors) have to have an opportunity to receive it at their own pace. Sometimes even when they make bad choices they need the freedom to know that they can make those choices. Otherwise, the church can become another place of pressure, just like the pimp. It's a kind of mind control, you're brainwashing her with, "You have to do things this way to fit in". They really need the freedom to make choices and discover their own place who they are. And there will be some trial and errors and some mistakes. And that person needs the freedom to be able to do it in order to find her way or his way back home. Just like the prodigal son.

On a very similar note, Carl emphasized the importance of allowing survivors to identify their own needs and how they would want to be supported by the church, this in fact being the very type of service that reflects God:

I can't remember who I first heard say this, but I think for anybody in the world, but especially for somebody in (anti-)sex trafficking in whatever capacity, the two best questions are "What hurts?" ... "How can we help?" ... It turns the agency over to the human actually experiencing the thing to ask first, "What hurts, what's wrong?" And then you get their idea of what's wrong. And then you come alongside to say "How can we help?" And again, it puts the ball in their court to have the goal, the thing that they want to move towards and have the mechanism as well. I feel like that is the work of God through Scripture. You know, as far back as the exodus right? God doesn't try to convert the Israelites. God hears their cry of slavery and frees them and then once they're free there's 
a relationship at Sinai... You know, I think we only emulate God when we ask those questions, "Where does it hurt and how can we help?"

Nonetheless, while all participants described survivors as being the experts regarding their own needs and approaches to intervention, only Pat described them as being the experts regarding trafficking. In speaking about the various training programs she had seen offered by state and church-related agencies, she observed, "People discount getting survivors involved in trying to develop programs that will actually work ... They're actually not getting to the heart of the issue, because they don't involve survivors or victims in the process".

\subsection{Theme 4: Managing Tensions}

The theme of managing tensions marked participants' responses. Two main areas of tensions were prominent: (i) managing the tensions between ideal and reality, and (ii) managing the tensions between different components of their constructions of reality. Table 3 summarizes key tensions that participants discussed and their management strategies.

Table 3. Managing the Tensions between Ideal and Reality.

\begin{tabular}{|c|c|}
\hline Tensions & Management Strategies \\
\hline $\begin{array}{l}\text { Simplicity of } \\
\text { salvation/anti- } \\
\text { trafficking }\end{array}$ & $\begin{array}{l}\text { - } \quad \text { Emphasizing that church discourses of anti-trafficking need to be } \\
\text { - } \quad \text { stretched to accommodate complexity }\end{array}$ \\
\hline
\end{tabular}

\begin{tabular}{cll}
\hline $\left.\begin{array}{c}\text { High Divine } \\
\text { mandate }\end{array}\right\rangle\left\langle\begin{array}{cl}\text { Reality of } \\
\text { limitations }\end{array}\right.$ & $\begin{array}{l}\text { Emphasizing that the church needs to change for the better } \\
\text { Partnering with others }\end{array}$ \\
Engaging in thoughtful and prayer-led distribution of resources
\end{tabular}

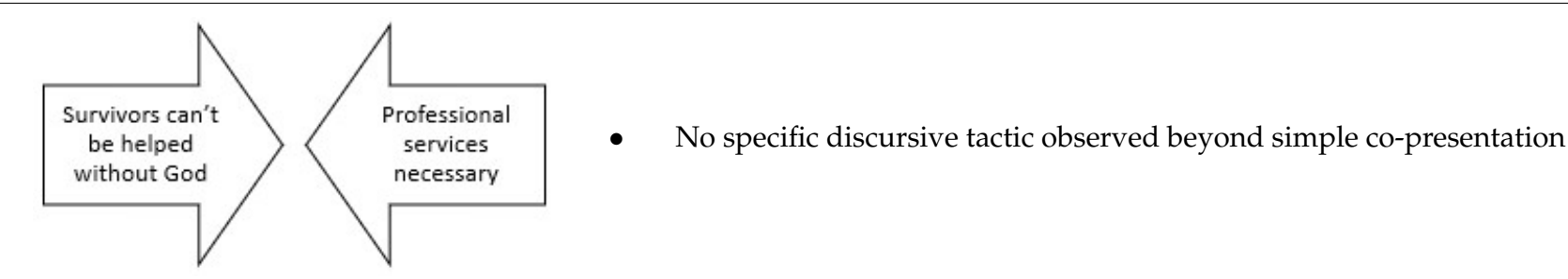

Managing the tensions between different components of their constructions of reality

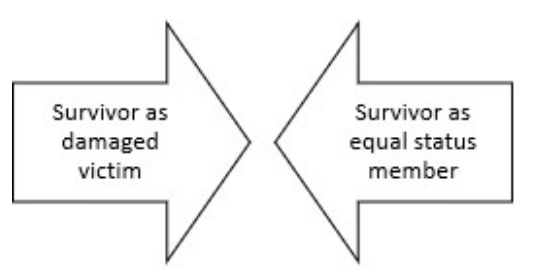

- $\quad$ Normalizing and universalizing survivors' struggles

- $\quad$ Emphasizing temporary nature of survivor struggles

- Disassociating trafficking experiences from identity

- Narratives of growth and achievement

- Narratives of special abilities conferred by trafficking experience on survivors 
Table 3. Cont.

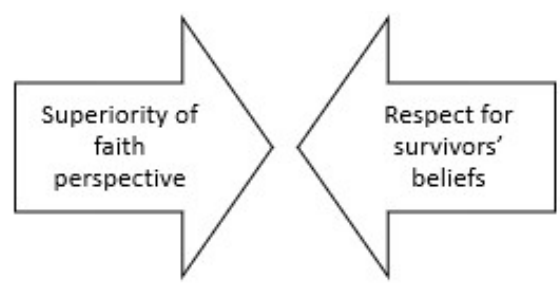

- $\quad$ Prioritizing respect for survivors' beliefs

- Prioritizing service allowing survivors to naturally gain interest in Christianity on their own volition without coercion

\subsubsection{Managing the Tensions between Ideal and Reality}

This theme denotes participants' attempts to navigate the complexity encountered when the ideals encapsulated in their construction of reality and their system of morality came in contact with the 'messy' realities of life. For instance, even as participants asserted that God wants Christians to help and would empower them to do so effectively, they also described the reality of how Christians are limited in their competencies and resources. Paul spoke to this clash between ideal and reality in his caution that churches to be thoughtful about how they use their resources:

I think that there is a responsibility to do what you can and what you're called to because every church is limited in its resources. To prayerfully consider in your specific churches who is in your community, who is in your neighborhood that you have a call to and what is in front of you that you could be engaged with. And I think that there's a responsibility to do what you can within the boundaries of the resources that you have. But I'll say this: I think that some of God's favorite people are the last, the least and the lost, and so people who are trafficked are high up on the list of God's favorite people that need to be reached out to.

Not only are Christians limited in what they have the skills and resources to accomplish for survivors, but they also face characterological issues, creating yet another tension between ideal and reality to manage. For example, Jennifer shared that she found that church members used "the excuse of being too busy" and struggled with "the fear of not knowing what to do or what to say, or even how to fix it". Several participants described their frustration with the lack of concern, moral strength, or willingness to be inconvenienced that they had observed in the church. For instance, Dana decried how the church was capable of being "disconnected" from, "shut down" regarding, and "not wanting to talk about" not only the issue of trafficking, but other issues such as pornography, drugs, rape, domestic violence, and racism. Harriet was blunt in her claim that church members were not above participating as consumers of trafficking: "One reason churches don't want to deal with this issue, I'll just say it bluntly, is that some of these johns may belong in our church".

Traditions and practices that hinder their ability to help and integrate survivors into their communities were also described, including gender bias, a lack of diversity, bureaucracy, bad planning, and unhealthy competition. For instance, when asked what are some challenges the church faces in helping survivors, Dana replied, "church rules", and explained that this factor "prevents us from moving forward (to help) when you have too many boards and too many hands on and too many rules and too many people to have to get answers from or get permission from". Matthew shared frankly that the "old boys' network" was a problem in his denomination, where the politics within his denomination means that "oftentimes outsiders are not necessarily welcome". Hilda noted that her congregation had not been able to be a hospitable place for a transgender survivor of sex trafficking, largely due to a lack of diversity: "What an awkward place to be, where you're the only transgender person and probably the only human trafficking survivor in the room". Paul referred to the intersection of stigma and sexism: 
We (in his childhood church) had a few people who had been formerly addicted to drugs, who were part of our community, but they were always sort of charity cases. They were not thought of as equal members; it was that we were helping them. Had we had someone who had been trafficked in that congregation, I think it would have been similar. They would be junior partners that were there to be helped, not equal partners. But that does beg the question I think about the power structure of churches. Like I don't know statistics, but I would imagine that males run the vast majority of churches in the US. That not seeing yourself in the leadership of the church and coming from an oppressive male dominated place as a trafficked person who are often, I would imagine, mostly trafficked by men. I could see that being very, very difficult for feeling comfortable and like you'd want to be integrated.

To manage the complexity and tension engendered when a discourse of Christians having a divine calling and divine empowerment for effective services encounters the limitations, moral failings, and inadequacies of the church, participants primarily employed a discourse of change; i.e., they attested that the church needed to change for the better (see the previous theme, 'immutability and change'). Notably, several participants also reflected on the inadequacy of a 'simple' understanding of trafficking encased in the typical evangelical understanding of salvation, and were explicit about the need for the churches' anti-trafficking paradigms to change to accommodate the on-the-ground complexities of trafficking and intervention. Deborah noted importance of understanding that sex trafficking does not "just happen" but rather "happens at the intersection of so many other issues: racism, poverty, homelessness, mental health and addictions, trauma..". Carl, in reflecting on the "very tidy" approaches to anti-sex-trafficking that he had encountered in churches, said,

I really think it comes back to soteriology and imitating the divine. If the only thing that matters is Jesus's death and then 3 days later, a resurrection, then, we're looking for simple and short solutions to problems that we don't want to have be too complex. But if you think about pre-resurrection life of Jesus as this decades-long interaction with a number of complex and really sticky, messy issues, like, what do we do about occupation? ... What do we do about, like, righteousness, both on a personal and a communal basis? What do we think about all of these different things? That kind of gets ignored. At least in my denomination, if I can be perfectly honest, we're not comfortable with a complex God, or a complex Jesus. And so we don't look for complex solutions. Well, like a quick bridge model. You know, that's like, sin separates humans from God, the cross is the bridge. Good. But there's a lot more to it. I don't say that's wrong, but there's a lot more to it, right? And if you have a two-sentence summary of all God's work in the world, why on earth are we reading the Bible? Why on earth are we praying? Why on earth are we studying? Why on earth are we getting together? Oh, 2 sentences, fine, that's all you need! Come on, you know, sure, it is all you need, but it's also a lot more complex than that.

Similarly, as much as participants described a construction of reality in which God was the ultimate source of survivors' healing and the Christian's empowerment to help survivors, they also acknowledged that survivors needed professional services, such as trauma treatment and housing services. Illustrating this, Eliza highlighted that the "best thing that the church can do is partner with the people who are already doing it", while also asserting in a later part of the interview, that "the one simple thing that changes everything else" is for survivors to "fall in love with Him and actually have a real God encounter". Similarly, Pat, who stated that "healing and deliverance" (spiritual interventions) were necessary for healing, also stated that professional counseling was needed and that no one should "rely on non-professionals, even me who is (healing) ministry trained". 
Our data analysis did not reveal participants employing specific strategies for managing this apparent contradiction beyond presenting both sets of claims as naturally coexistent. In fact, several participants, when listing the things that survivors needed, despite noting at different places in their interviews that God was the ultimate source of healing or transformation, would cite both spiritual interventions and resources alongside professional or secular services. For example, Paul shared, regarding his church's approach to helping survivors and others in need, "We like to blend the practical with the psychological with the spiritual so depending on where people are at, "What do you need right now?", "What kind of counsel do you need?" and then "How can we see to your spiritual needs?"'".

\subsubsection{Managing the Tensions between Different Components of Their Constructions} of Reality

The theme of 'managing tensions' also highlights participants' attempts to navigate the complexity produced when different components of their constructions of reality or their system of morality seemed contradictory. One area of complexity that participants put much effort into navigating was the apparent contradiction inherent to framing survivors as victims in need of rescue while simultaneously framing them as individuals of incredible worth, courage, and potential. A distinct strategy employed to navigate this particular tension included normalizing and universalizing survivors' struggles. Tina exemplifies this strategy, stating that "A successful survivor is somebody that is consistently walking in their new identity. Because for years I struggled with that too and realizing, like, therefore, there is now no condemnation in Christ". In an even more explicit example, Dawn shared, "I had strong people in my life that supported me that poured into me, discipled me, counseled me so you (the survivor) need a very strong support group".

Survivors' struggles were not only universal, but also temporary. For instance, Jenny, one of the pastors who had also worked with survivors in a professional context for over twenty years noted, "Everything changes for them (when they learn to trust). They really do become the overcomer. They don't have to fear anything anymore, if they learn to trust God in their lives. They've learned to trust others, to go on with their lives as well. I think they just have arrived when they get that". Joan stated simply, "The past does not define anyone".

Another strategy used was to emphasize that not only did survivors' victimization not devalue them, but those experiences conferred on them qualities and competencies that no one else has. Again, Tina exemplified this with her description of how survivors can do what other people cannot: “They've survived. They've gotten out, they're on the path to victory. And they're basically a breaker for other people follow that path and get out of it themselves. They are catalysts". Similarly, Jane noted, "I admire people that have come through or come out of horrible places or lifestyles and God's done a miraculous thing", as "they are able to help people that others cannot". In the same vein, Jenny described survivors as possessing traits valued in the Bible by dint of their experience: "It's like that Bible verse: suffering produces perseverance, perseverance, character and character, hope. That's exactly what I see when I say there's a depth in survivors that I rarely see in others who aren't challenged in their lives to overcome anything".

Interviewees also evoked narratives of transformation, growth, and achievement. Survivors were described as "overcomers", "victorious", and by other words that index prestige, success, and sustained effort through difficulties. These new definitions, categories, or labels supplanted any negative ones created by having been trafficked, and were accompanied by interviewees' stated and/or prosodic expressions of appreciation and admiration for survivors. To further bridge the tension, participants also employed kinship terms as proof of survivors' irrefutable worth amidst victimization and its aftermath For instance, Joan was careful to be extremely clear that victimization did not degrade their worth:

I see the brokenness. So I think that they are broken. But, you know, not in a judgmental way. I think they were hurt. They're victims. But I also see 
"precious". I see them as daughters. I think that's one picture that really comes out that they're all someone's daughter. And even if they are orphans, or even if they were abandoned, they're God's daughter. So because of that, they have incredible worth and the fact that they're broken is just something that needs to be restored.

Another area where several participants managed contradictory components of their constructions of reality or morality was in the tension between the missional aspects of their faith (converting others into Christianity, as it is the perfect source of happiness, hope, and blessing and only escape from eternal damnation) and respect for survivors' beliefs. Respectful caution was one strategy. For example, when Kathy was asked by a survivor whom she knew to be Christian about horseback riding, she was still careful to ask if the survivor would be alright with encountering talk about God from the Christian viewpoint: "Hey, I know of a place that does horseback riding, it's a faith based organization, they're going to talk about God. She's like, 'I'm fine with that'". Participants also prioritized "showing love" for and "meeting needs" of survivors as the first priority, explaining that when done authentically this would naturally draw survivors to Christianity without coercion. For example, Joan described the process so:

I just always think of when Jesus healed, He healed people and gave them what they asked for ... He didn't say, "Well, are you going to believe in me first". So we need to give them what they need, first, and I think it's a lot of love initially.

Others, such as Jonathan, who had extensive experience running multiple faith-based nonprofits, managed the tension with a focus on the moral responsibility to do good over making converts. He noted, "Both academia and the church have to deal with the issue of grappling with church's 'ulterior motives'". He described attempting to share this focus with his own nonprofit board members, "If your motivation is always going to be that we are only successful when we can point to names written in the Lamb's Book of Life (conversions), then that's going to be a really bad platform for our ministry, for our partnerships". He asserted, "God hates injustice intrinsically -it's offensive to him because God himself is a father to children, to the fatherless". Addressing issues of injustice is intrinsically good regardless of whether anyone ever 'gets saved' or converted to Christianity. In short, participants displayed care to ensure that making converts does not become the "ulterior motive" of their philanthropic activities.

\section{Discussion}

The themes developed out of interviews with Christian faith leaders demonstrate that being a Christian means viewing sex trafficking from a faith-based worldview. This is primarily marked by: (1) the belief that God cares about sex trafficking and the Christian therefore has a moral obligation to intervene; (2) the belief that God, the Christian, and the survivor all have essential roles in the overarching narrative of helping humanity; and (3) continuous attempts to effectively apply their faith or moral principles in a complex and imperfect world. These three markers rest on a fourth-a commitment to the 'objective truths' that are foundational to their faith-based worldview, including the truths about God, the survivor, and the Christian. Participants' depictions of these truths mainly foregrounded the loving, powerful, and good nature of God, and the inherent immutable value and potential for good that all human beings have, including survivors.

Participants' responses provide an opportunity to discuss evangelical Christian countertrafficking through evangelical Christian leaders' first-person perspectives and to triangulate these perspectives with current critiques of evangelical counter-trafficking. In particular, we note that interviewees' responses displayed sensitivity to issues of relative privilege and power as "helpers" (Bernstein 2018, p. 166). For instance, participants caution against treating survivors like "charity cases", negating their agency, and ignoring the nuances and complexities of their lives. They emphasized the importance of allowing services to be informed by survivors' agency, expectations, and needs, with the outstanding example 
being where one pastor likened less respectful approaches to the church behaving "just like the pimp". They also emphasized that their faith-based moral values and moral action must respect the diverse perspectives held by survivors and other potential partners in the community. That is, participants appeared to be taking especial care to be distinctly faith-inspired without being ideological or imposing their morality or agendas on others, and also recognized the need to be circumspect about how power differences could affect their interactions with survivors.

Also notable was the reflexivity in participants' responses. Several participants brought up the inadequacy of the narratives that drive current counter-trafficking efforts by evangelicals, and related this problem to a larger and equally oversimplified 'salvation narrative' that they described as being part of evangelical church culture. In addition to examining the validity of the specific trafficking narratives and metanarratives that have inspired the evangelical church to social action (or rather, to oversimplistic strategies), all participants reflected rather extensively on the problems within the church that prevent an authentic or productive engagement in social justice efforts. This reflexivity indicates that participants were not only willing to interrogate their own moral positions with regard to sex trafficking and other social issues, but also see such interrogation as necessary.

These findings imply that evangelical counter-traffickers may share more knowledge and values with those who critique them than the current body of critical literature would suggest. Prominent and important shared concerns include; (1) respectfully participating in a diverse community; (2) finding ways to address flaws in evangelical social justice efforts and counteract evangelical Christian cultural practices/paradigms or scarcity of resources/knowledge that generate the flaws; and (3) accommodating complexity. The alignment of these concerns could be the starting point for a productive dialogue and the sharing of strengths between evangelical Christian counter-traffickers and academics involved in trafficking-related matters.

We also noted, however, two disconcerting findings that would be critical to address through an inclusive dialogue with all involved parties. First, several interviewees distinguished between a generalized mandate to all Christians to engage in social justice activities and a more specific mandate to some Christians to engage in anti-trafficking. Nonetheless, despite their explicit emphasis on survivor agency, they claimed that after being helped, all survivors should be helping other survivors. In addition, rather inexplicably, these interviewees did not seem to consider that survivors, after being helped, might not want to be engaged in helping other survivors, or-evoking the narrative of discovering one's divine purpose mentioned by interviewees - that God might have a different plan for the survivor. Interviewees did not seem conscious of the discrimination inherent in giving Christian survivors a restricted range of socially prestigious roles within the Christian community. The impact of such discrimination, as well as the narratives that foster it, needs to be further examined, particularly through research designs that bring evangelical church members and survivors together in meaningful dialogue, since only survivors can speak to what survivors actually want to do and how they are impacted by others' assumptions.

Second, the interviews revealed a lack of acknowledgement of survivors' traffickingrelated expertise. While interviewees generally depicted survivors as being the experts regarding their post-trafficking needs and cautioned against imposing white middle class standards of 'success' on survivors, only one interviewee actually stated that it was important to incorporate survivors' knowledge about trafficking into intervention, education, and training efforts. To address the need for the evangelical church to be informed by survivors' expertise in its trafficking-related perspectives and services, it would be critical for social work and other fields to assist churches to form or partner with survivor-led groups (Gerassi et al. 2017; Knight et al. 2021a). Such groups are invaluable for bringing survivors' perspectives and expertise to the table (Gerassi and Nichols 2018). They can also act as a bulwark against the salvation discourses in specific congregations reaching extremeswhere survivors are indeed only permitted victim roles, or highlight and correct more subtle forms of discrimination (Twis and Praetorius 2021). 
Overall, from their own standpoints, as evidenced throughout the interviews, participants held to the epistemic superiority of their interpretations of Christianity. Their social locations as Christians who pay attention to God and seek direction or revelation from Him gave them the capacity and authority to generate this superior knowledge which carries both pragmatic and moral value. Participants' views of survivors as needing salvation (help and rescue) were embedded within a larger faith-based narrative wherein all human beings, including themselves, need salvation (help and rescue). At the same time, they were generally careful to underscore the fundamental place of human agency and non-coercion regarding what that action, help and rescue would entail.

Acknowledging the "situated knowledge" (Pierre 2014) of evangelical Christians involved in counter-trafficking would provide an alternative pathway through the critiques of Christian anti-trafficking. It potentially replaces the concerns of "this is how evangelical Christians think (repressively and pejoratively) about 'sex trafficking victims"' with "this is how Christians think about who people are and what people need, as informed by a specific congregation's interpretation of scripture and tradition" as a base for further inquiry and dialogue. Instead of framing the issue around the ideological differences regarding women's rights (including the rights to their own bodies and to perform their preferred forms of emotional or sexual labor), perhaps the issues could be framed as being about 'cultural differences' to be bridged between the different feminist worldviews and the various evangelical Christian worldviews.

The reframing of the critiques in the terms of standpoint theory also provides guidance as to what aspects of the knowledge claims made must continue to be scrutinized. Every "situated knower" has privilege over the subject matters pertaining to themselves (Anderson 2020); when one group claims to have knowledge about another group - whether it is academia claiming knowledge about Christians, or whether it is Christians claiming knowledge about sex trafficking survivors - then circumspection and interrogation become urgent and essential. This is particularly true when one group's claims about another group become part of an established policy- and practice-influencing discourse. As the knowledge claims are made about another group, the circumspection and interrogation necessarily has to incorporate the situated knowledge of that group; i.e., people in one social location who make claims about others in different locations must seek the expertise of these others regarding the claims. For instance, as mentioned earlier, evangelical counter-traffickers should certainly be asking survivors if they want or feel an obligation to help other survivors, and not presume the veracity of their assumption regarding this matter. The responsible management of privilege (whether it is institutional 'privilege' or the 'privileged' knowledge of the oppressed) means engaging in deliberate efforts to create an intersection between the social locations of the different knowers.

The discriminatory assumptions still evident in the data and the lack of acknowledgement of survivors' knowledge suggest that evangelical counter-traffickers very much need to be on a journey of creating such intersections with survivors in order to integrate survivors' expertise into their views of trafficking. Additionally, the interviews revealed shared areas of concern between evangelical Christian counter-traffickers and academics regarding evangelical counter-trafficking. That such areas of shared concern exist, but have largely not yet been discussed in extant academic critiques, highlights the importance of evangelical Christian representation in academic discourse of trafficking to create intersections between the knowers in academia and the knowers in evangelical churches.

\subsection{Implications}

The critical perspectives of people at diverse intersections of faith-based, secular, humanist, and feminist reasoning, experiences, and backgrounds are needed to enrich and inform trafficking discourses. A diverse community of inquiry could generate a robust epistemic and pragmatic exchange, creating the theoretical and methodological pluralism needed respond to the complex and changeable social, economic, and political realities. That is, trafficking academics, Christian counter-traffickers, survivors, and other 
involved parties must come together to engage in the following feminist norms of inquiry (Anderson 2020): emotional engagement, reflexivity, and democratic discussion.

Emotional engagement. Emotional engagement with each other and the standpoints occupied by the other promotes epistemic fruitfulness (Anderson 2020). "Emotions serve critical epistemic functions in moral and political enquiry, attuning observers to evaluatively relevant features of the world" Anderson 2020, para. 75). This entails setting aside current prejudices, biases, or judgments about the others that could impede knowledge inquiry, including prior positive/negative assumptions. This may be challenging for the different groups involved-for instance, some survivors who have had negative experiences with the faith-based community (Cojacaru 2016) and the academic community (Gerassi et al. 2016) and scholars have noted a mistrust of social workers by the faith-based community and vice versa (Zellmer and Anderson-Meger 2011; Hodge 2019). However, the challenge is worth facing if such a dialogue can produce more cohesive efforts towards promoting social justice in its diverse forms.

Reflexivity. Dialogic reflexivity reduces the likelihood that one group might confuse its own partial perspectives with a comprehensive view (Anderson 2020). It enables experiences or truths that may be difficult for one group to acknowledge to not remain hidden but instead become areas of active and collaborative investigation. For instance, it may be difficult for Christian counter-traffickers to realize that some of their counter-trafficking strategies are viewed as demeaning by survivors (Twis and Praetorius 2021), but it will be difficult for them to gloss over this issue if survivors themselves are speaking directly to this issue. Academics would have to consider the implications of hearing from both survivors who state that they favor evangelical counter-trafficking approaches because of their positive personal experiences and survivors who report being harmed or denigrated by such approaches. In particular, for a social justice conceptualization such as sex trafficking, with the questions of its moral and legal legitimacy, a shared reflexivity may help prevent the vested interests of particular groups from being ideologically misrepresented as coinciding with universal human interests (Kempadoo 2012).

Democratic discussion. Knowledge inquiry as a shared enterprise between inquirers occupying different standpoints enables knowledge and understandings to disseminate between different groups, reducing patterns of ignorance (Margonis 2007). It also provides ample opportunity to inquirers to respond to criticisms from all points of view, with shared dialogic standards of evaluation. For instance, academics and Christian counter-traffickers could identify and interrogate any simple binaries they find in each other's trafficking discourses and help each other become more aware of how their particular situations impact their abilities to know. Starting at their shared understanding of trafficking as an area of victimization that requires intervention, academics and Christians could integrate different conceptualizations of the roles that socio-cultural, economic, and political factors play in shaping trafficking to arrive at a common strategy for addressing trafficking. Such a strategy would synthesize the most useful of the practical and theoretical knowledge of both parties, while avoiding their respective biases or practiced ways of looking at trafficking that would hinder innovation or progress.

Coming together to engage in these norms of inquiry should occur across a variety of settings. Formal discussions could be arranged with the leaderships of various evangelical denominations and independent churches. Roundtable and panel discussions could be held at both academic and Christian conferences and at anti-trafficking trainings held for Christian communities. These issues should also be raised on the television shows, podcasts, and other media of popular evangelical Christian leaders. Training in religious and spiritual competence for academics may be helpful for promoting successful engagement with religious leaders (Hodge 2019). Furthermore, academics and those in the helping professions, such as social work, should where possible take advantage of more micro-level interactions to promote these norms of inquiry. For instance, social workers within Christian counter-trafficking activist groups or social service agencies could promote the input of 
survivors with diverse backgrounds on the agency's trafficking narratives and intervention practices (Twis and Praetorius 2021).

\subsection{Future Research}

As this paper has focused on the representation of evangelical Christian pastors, future research could include other Christians who have been increasingly involved in anti-trafficking (Bernstein 2018), such as those with more liberal, moderate, or progressive Christian leanings. Additionally, considering how various religious and spiritual groups have engaged in counter-trafficking work (Knight et al. 2021a) and have the potential to influence a very large percentage of the world's population (Global Freedom Network 2014), it would also be important to investigate (1) how other religions have contributed to the work, (2) how different religious groups can best collaborate to address trafficking, and (3) how secular and religious groups can best collaborate to address trafficking. Additionally, as faith and spirituality promote survivors' resilience (Knight et al. 2021b), but survivors are often from vulnerable populations who can be subject to the agendas of the 'helpers', research should be conducted on survivors' positive and negative experiences with different faith communities in order to educate and promote best practices within these faith communities.

\subsection{Strengths and Limitations}

While this study has several strengths, we also note there were constraints on the design and data analysis phases with the potential to impact study finding. First, both authors have intersecting identities as both Christians and social workers and were therefore able to negotiate the values and norms- both those which are divergent and those which are aligned. However, we cannot know for sure if the interpretations and presentation of these data could have differed had the team integrated a Christian academic who was not a social worker, a social work academic who was not a Christian, or collaborators with any other intersecting identities. The study included an advisory committee of pastors who were consulted as needed in the design, data collection, and initial analysis of findings. The information and critique provided by this external group of advisors acted as a safeguard to ensure the study's fidelity. However, due to time constraints, the authors did not share a version of this manuscript with the advisory committee for their feedback before submission to this journal. Several strategies were used to collect rich and comprehensive data, including the invitation to all respondents to participate in follow-up interviews. In addition to exploring emergent themes, these second-round interviews also worked as member check-in sessions where participants had the opportunity to elaborate and clarify their thinking. Further, the integration of virtual interviewing technologies helped facilitate this extended participant contact. However, we also acknowledge that by not providing all respondents with the added opportunity to read through and reflect on both interview transcripts diminishes the strength of these findings. Finally, while the study was able to enroll pastors from several denominations and with a range of experiences both in pastoral care and in the human trafficking field, we are cognizant that this recruitment does not capture perspectives from all major denominations, though we had tried to recruit a diverse sample.

\section{Conclusions}

Any religious bias among us trafficking scholars must be addressed as much as in any other social context. Viewpoints informed by faith or spirituality, including those hailing from traditional monotheistic religions, should not be withheld privilege in academic discourse, particularly as those from disadvantaged populations tend to have a large proportion of members with monotheistic faith commitments. These include ethnic and racial minorities, those with lower incomes, rural communities, women, older adults, and immigrants (Harr and Yancey 2014; Hodge 2013; Newport 2012; Pew Research Center 2015). Counter-trafficking discourse appears to have seen more progress in terms of diversity 
regarding queer and anti-racist commitments (Xian et al. 2017) than it has regarding religion, though progress in all three areas is still desperately needed. It is vital that the different groups involved engage in genuine dialogues which provide the opportunity to reflect on how different parties view each other's standpoints and the assumptions underlying these views. These dialogues would also ameliorate the natural tendency to defend one's own positions while diminishing the contributions of those who have other paradigms, producing more progressive and practical knowledge. Most importantly, such dialogues create relationships. Among the uneasy differences engendered by different standpoints, such relationships could still make amiable or fruitful partnerships feasible regarding important matters, including labor conditions, migration rights, gender rights, access to care, and education for the individuals and communities that all parties have an interest in (for whatever reasons they have).

Author Contributions: Conceptualization, L.K.; Data curation, N.K.; Formal analysis, L.K. \& N.K.; Funding acquisition (internal funds to cover publication cost), N.K.; Methodology, L.K.; Supervision, N.K.; Writing—original draft, L.K. and N.K.; Writing—review \& editing, L.K. and N.K. All authors have read and agreed to the published version of the manuscript.

Funding: This research received no external funding.

Institutional Review Board Statement: The study was conducted in accordance with the Declaration of Helsinki, and approved by the Institutional Review Board (or Ethics Committee) of The Ohio State University (2020B0060 28 June 2020).

Informed Consent Statement: Informed consent was obtained from all subjects involved in the study.

Data Availability Statement: Data not available to protect privacy and confidentiality of participants.

Conflicts of Interest: The authors declare no conflict of interest.

\section{Notes}

1 This refers to when survivors are given "token" (Yoder 1991) inclusion in trafficking-related matters without their ideas and perspective being truly respected or integrated into policy and practice, and/or when the survivor is used to inaccurately "represent" a larger group or more diverse spread of survivors which can falsify the credibility of an organization's practices or agendas (Gerassi and Nichols 2018).

2 Here, and throughout this paper, we use the gendered pronouns 'he/him/his' to refer to God as participants themselves use these pronouns. Framing God as male is a typical and historical practice in many Christian communities.

\section{References}

Anderson, Elizabeth. 2020. Feminist Epistemology and Philosophy of Science. In The Stanford Encyclopedia of Philosophy. Edited by Edward N. Zalta. Stanford: Stanford University. Available online: https:/ / plato.stanford.edu/archives/spr2020/entries/ feminism-epistemology/ (accessed on 1 November 2021).

Bamberg, Michael. 2012. Why narrative? Narrative Inquiry 22: 202-10. [CrossRef]

Bernstein, Elizabeth. 2018. Brokered Subjects: Sex, Trafficking and the Politics of Freedom. Chicago and London: The Chicago University Press.

Bruce-Briggs, Barry. 1979. The New Class? Piscataway: Transaction Publishers.

Bryant-Davis, Thema, and Pratyusha Tummala-Narra. 2017. Cultural oppression and human trafficking: Exploring the role of racism and ethnic bias. Women \& Therapy 40: 152-69. [CrossRef]

Campbell, Letitia M., and Yvonne C. Zimmerman. 2014. Christian ethics and human trafficking activism: Progressive Christianity and social critique. Journal of the Society of Christian Ethics 14: 145-72. [CrossRef]

Cojacaru, Claudia. 2016. My experience is mine to tell: Challenging the abolitionist victimhood framework. Anti-Trafficking Review 7: 12-38. [CrossRef]

Cooper, David E. 1999. Epistemology: The Classic Readings. Hoboken: Wiley-Blackwell.

Davidson, Larry, and David Stayner. 1997. Loss, loneliness, and the desire for love: Perspectives on the social lives of people with schizophrenia. Psychiatric Rehabilitation Journal 20: 3. [CrossRef]

De Perez, Julie L. 2015. Examining trafficking statistics regarding Brazilian victims in Spain and Portugal. Crime Law Soc Change 63: 159-90. [CrossRef]

Eckert, Penelope. 2000. Linguistic Variation as Social Process. Malden and Oxford: Blackwell.

Farley, Melissa. 2006. Prostitution, trafficking, and cultural amnesia: What we must not know in order to keep the business of sexual exploitation running smoothly. Yale Journal Pf Law and Feminism 18: 109-44. 
Fraser, Heather, and Christiana MacDougall. 2017. Doing narrative feminist research: Intersections and challenges. Qualitative Social Work 16: 240-54. [CrossRef]

Gerassi, Laura, Andrea J. Nichols, and Erica Michelson. 2017. Lessons learned: Benefits and challenges in interagency coalitions addressing sex trafficking and commercial sexual exploitation. Journal of Human Trafficking. [CrossRef]

Gerassi, Laura B., and Andrea J. Nichols. 2018. Sex Trafficking and Commercial Sexual Exploitation: Prevention, Advocacy and TraumaInformed Practice. New York: Springer Publishing Company, LLC.

Gerassi, Laura B., Tonya Edmond, and Andrea Nichols. 2016. Design strategies from sexual exploitation and sex work studies among women and girls: Methodological considerations in a hidden and vulnerable population. Journal of Action Research 15: 161-76. [CrossRef]

Global Freedom Network. 2014. A United Faith Against Modern Slavery: The Joint Declaration of Religious Leaders Against Modern Slavery. Available online: www.cdn.walkfree.org (accessed on 1 November 2021).

Harr, Cynthia R., and Gaynor I. Yancey. 2014. Social work collaboration with faith leaders and faith groups serving families in rural areas. Journal of Religion E Spirituality in Social Work: Social Thought 33: 148-62.

Heidegger, M. 2005. Introduction to Phenomenological Research. Bloomington: Indiana University Press.

Hodge, David R. 2006. Do conceptualizations of spirituality and religion affect perceptions of compliance with the ethical standards that address religion? An exploratory study. Journal of Religion E Spirituality in Social Work: Social Thought 25: 1-18. [CrossRef]

Hodge, David R. 2013. Religious conscience protection: A critical important human right for an increasingly diverse society. Journal of Religion and Spirituality in Social Work: Social Thought 32: 131-44. [CrossRef]

Hodge, David R. 2019. Increasing spiritual diversity in social work discourse: A scientific avenue toward more effective mental health service provision. Social Work Education 38: 753-65. [CrossRef]

Hodge, David. R. 2020. Religious congregations: An important vehicle for alleviating human suffering and fostering wellness. Journal of Religion E Spirituality in Social Work: Social Thought 39: 119-37. [CrossRef]

Jackson, Crystal A., Jennifer J. Reed, and Barbara G. Brents. 2017. Strange confluences: Radical feminism and evangelical Christianity as drivers of US neo-abolitionism. In Feminism, Prostitution and the State. London: Routledge, pp. 66-85.

Jasper, Melanie A. 1994. Issues in phenomenology for researchers of nursing. Journal of Advanced Nursing 19: 309-14. [CrossRef] [PubMed]

Kempadoo, Kamala. 2012. Abolitionism, criminal justice, and transnationl feminism. In Trafficking and Prostitution Reconsidered. Edited by Kamala Kempadoo, Jyoti Sanghera and Bandana Pattanaik. Boulder: Paradigms Publishers, pp. vii-xlii.

Knight, Logan, Kaitlin Casassa, and Njeri Kagotho. 2021a. Dignity and worth for all: Identifying shared values between social work and Christian faith-based groups' anti-sex trafficking discourse. Journal of Religion E Spirituality in Social Work: Social Thought, 1-20. [CrossRef]

Knight, Logan, Yitong Xin, and Cecelia Mengo. 2021b. A scoping review of resilience in survivors of human trafficking. Trauma, Violence, \& Abuse 6: 482-93. [CrossRef]

Levy, Alexandra, and Martina Vandenberg. 2016. When "Mandatory" Does Not Mean Mandatory: Failure to Obtain Criminal Restitution in FEDERAL Prosecution of Human Trafficking in the United States. The Human Trafficking Pro Bono Legal Center. Available online: http:/ / www.htprobono.org/htpro-bono-mandatory-restitution-restitution-report-9-2014 (accessed on 1 November 2021).

Levy, Jay, and Pye Jakobsson. 2014. Sweden's abolitionist discourse and law: Effects on the dynamics of Swedish sex work and on the lives of Sweden's sex workers. Criminology and Criminal Justice 14: 593-607. [CrossRef]

Linde, Charlotte. 1993. Life Stories: The Creation of Coherence. Oxford: Oxford University Press.

Longino, Helen. 1990. Science as Social Knowledge. Princeton: Princeton University Press.

Longino, Helen. 2001. The Fate of Knowledge. Princeton: Princeton University Press.

Margonis, Frank. 2007. John Dewey, WEB du Bois, and Alain Locke: A Case Study in White Ignorance and Intellectual Segregation. In Race and Epistemologies of Ignorance. Edited by Shannon Sullivan and Nancy Tuana. New York: Suny Press, pp. 173-95.

Marsden, Peter V. 1987. Core discussion networks of Americans. American Sociological Review 52: 122-31. [CrossRef]

Merleau-Ponty, Maurice. 1962. The Phenomenology of Perception. London: Routledge and Kegan Paul.

Miles, Matthew B., and A. Michael Huberman. 1994. Qualitative Data Analysis: An Expanded Sourcebook. Thousand Oaks: Sage.

Milroy, Lesley, and Milroy Gordon. 2003. Sociolinguistics: Method and Interpretation. Malden and Oxford: Blackwell.

Newport, Frank. 2012. God Is Alive and Well: The Future of Religion in America. New York: Gallup Press.

Pew Research Center. 2015. The Future of World Religions: Population Growth Projections, 2010-2050. Available online: https: / / www.pewforum.org/2015/04/02/ religious-projections-2010-2050/ (accessed on 1 November 2021).

Pierre, J. 2014. Standpoint Theory. Available online: https:/ / eugenicsarchive.ca/discover/tree/53d831e14c879d0000000011 (accessed on 20 October 2021).

Polkinghorne, Donald E. 1995. Narrative configuration in qualitative analysis. International Journal of Qualitative Studies in Education 8: 5-23. [CrossRef]

QSR International Pty Ltd. 2020. NVivo. Available online: https://www.qsrinternational.com/nvivo-qualitative-data-analysissoftware/home (accessed on 1 November 2021).

Saldaña, Johnny. 2016. The Coding Manual for Qualitative Researchers, 3rd ed. Thousand Oaks: Sage. 
Sanders, Savannah. 2015. Sex Trafficking Prevention: A Trauma-Informed Approach for Parents and Professionals. Scottsdale: Unhooked Books.

Sanghera, Jyoti. 2012. Unpacking the trafficking discourse. In Trafficking and Prostitution Reconsidered: New Perspectives on Migration, Sex Work and Human Rights. Edited by Kamala Kempadoo. Boulder: Paradigm, pp. 3-24.

Schilling-Estes, Natalie. 2001. Variation Study and Discourse Analysis: The Sociolingustic Interview as a Situational Speech Event. New Ways of Analysing Variation. Raleigh: North Carolina State University.

Smith, Jonathan A., and Mike Osborn. 2015. Interpretative phenomenological analysis as a useful methodology for research on the lived experience of pain. British Journal of Pain 9: 41-42. [CrossRef] [PubMed]

Taylor, Charles. 1985. Interpretation and the Sciences of Man. In Philosophy and the Human Sciences, 2nd ed. Volume of Philosophical Papers. Cambridge: Cambridge University Press, pp. 15-57.

Twis, Mary, and Regina Praetorius. 2021. A qualitative interpretive meta-synthesis of evangelical Christian sex trafficking narratives. Journal of Religion E Spirituality in Social Work: Social Thought 40: 189-215.

United Nations. 2021. Sustainable Development Goals. Available online: https://unstats.un.org/sdgs/metadata/?Text=\&Goal=16 \&Target $=16.2$ (accessed on 1 November 2021).

United States Department of State. 2020. Trafficking in Persons Report; Washington, DC: Office of the Under Secretary for Global Affairs.

Wimpenny, Peter, and John Gass. 2000. Interviewing in phenomenology and grounded theory: Is there a difference? Journal of Advanced Nursing 31: 1485-92. [CrossRef]

Xian, Kathryn, Shaylin Chock, and Dustin Dwiggins. 2017. LGBTQ youth and vulnerability to sex trafficking. In Human Trafficking is a Public Health Issue. Cham: Springer, pp. 141-52.

Yoder, Janice D. 1991. Rethinking tokenism: Looking beyond numbers. Gender and Society 5: 178-92. [CrossRef]

Zellmer, Debra Daehn, and Jennifer I. Anderson-Meger. 2011. Rural Midwestern religious beliefs and help seeking behaviors: Implications for social work practice. Social Work and Christianity 38: 29-50.

Zimmerman, Yvonne. C. 2010. From Bush to Obama: Rethinking Sex and Religion in The United State's Initiative to Combat Human Trafficking. Journal of Feminist Studies in Religion 26: 79-99. [CrossRef]

Zimmerman, Yvonne. C. 2012. Other Dreams of Freedom: Religion, Sex and Human Trafficking. Oxford: Oxford Press. 